https://doi.org/10.46344/JBINO.2021.v10i02.09

\title{
INDIGENOUS WATER FILTER TO IMPROVE QUALITY OF WASTEWATER FOR IRRIGATION AND ITS EFFICACY.
}

Dhruvi N. Nirmal, Shivani S. Kamat, Siddharth P. Sagar and Jayaprada Rao Chunduri.

Department of Biotechnology; Mithibai College of Arts Chauhan Institute of Science \& Amrutben Jivanlal College of Commerce and Economics (Autonomous); Vile Parle (W); Mumbai - 400046; Maharashtra; India.

Email ID: dhruvinirmal2001@gmail.com

\begin{abstract}
Wastewater farming includes cereal, horticulture, floriculture, fodder crops and even aquaculture. In the urban areas, small scale farming practices include the agriculture of green leafy vegetables that are considered to be rich in $\mathrm{Fe}, \mathrm{Mg}$, comprise fibers and vitamins. Vegetables grown on waste lands of the urban areas often utilize wastewaters of domestic and industrial origin. Heavy metal load due to inlet of industrial effluents and sewage water leads to bioaccumulation of metals in plants and vegetables that enters the human body. Apart from the essential elements, the heavy metals in food cause various disorders including neurological and genetic, instead of preventing nutrient based current generation problems such as early balding, digestive problems, weak immunity. Qualitative and quantitative analyses of Spinach sample collected from drainage water irrigated fields of Goregaon, Mumbai using laboratory grade chemical tests indicated the presence of heavy metals $\mathrm{Pb}, \mathrm{As}, \mathrm{Cd}, \mathrm{Hg}, \mathrm{Fe}, \mathrm{Ni}, \mathrm{Co}$, and Mo in high concentration. During the current study an indigenous filter has been developed of low budget cost and farmer friendly which can reduce the heavy metal load from such irrigation waters. The qualitative and quantitative parameter of heavy metal composition in sewage waters before and after filtration by prototype were assessed using ICP-AES. The values reduced to detectable to no detectable ranges i.e.0.01 $\mathrm{Mgml}^{-1}$. Thus, the filter is proven to be $95 \%$ functionally efficient and made up of environmentally friendly, reusable materials.
\end{abstract}

Key words: Heavy metals, bioaccumulation, water filter, filter fabrics, water pollution, wastewater. 


\section{Introduction:}

Environmental research studies indicated the use of untreated wastewater from cities to irrigate the crops at global level. In countries like India, China, Pakistan, Mexico and Iran, the cropland is irrigated by dirty wastewater. India requires water majorly for irrigation (74\%), while the rest of $26 \%$ water consumption is for drinking $(7 \%)$, industry (4\%) energy (9\%) and others (6\%) as per the 2050 projections for India reports (CPCB, 2009). The usual domestic wastewater and uncontrolled industrial discharges contribute to heavy environmental pollution and potential health hazards (Rawat, et.al, 2009). On the contrary, smallholder farmers living in cities and peri-urban areas are the primary users of wastewater who reuse it for irrigation.

Early balding, premature loss of hair pigment, lack of immunity, shortening of reproductive age, young age heart attack, etc. are some of health issues faced by young generation in the current century. These ailments' control depends on the availability, uptake, and transport of nutrients, including amino acids/ proteins, calories, trace elements, and vitamins (Gold, et.al., 1971) (Tea, et.al., 2013). Cardiovascular diseases like heart stroke, atherosclerosis, peripheral artery disease, hypertension, etc., features a probability to be related to unhealthy dietary patterns (i.e., excessive intake of sodium and processed foods; added sugars; unhealthy fats; low intake of fruit and vegetables, whole grains, fiber, legumes, fish, and nuts), alongside a scarcity of exercise, overweight and obesity, stress, alcohol consumption, or smoking (Artinian, et.al., 2010) (Lancet, 2015) (Anand, et.al., 2015).

In a country like India where the population is nearly to succeed in an asymptote, with the rise in population the rise in demand for basic necessities like food and shelter has led to the utilization of the wastewater for agricultural practice by the farmers. At many places in an overcrowded city like Mumbai agriculture along railway tracks may be a common practice. Sewage water is employed for agriculture due to shortage of water (Doshi, et.al., 2014). With this scenario, the concept of bioaccumulation features a great role to play in describing the connection between heavy metals and plants. Studies have indicated that green leafy vegetables like lettuce and spinach can accumulate heavy metals above security limits from sewage water contaminated by industrial, agricultural, and mining effluents (Danjuma, et.al., 2018). The ingestion of such vegetables causes serious human health issues, like gastrointestinal cancer, fragile immunological mechanisms, mental growth retardation, and malnutrition (lyengar, et.al., 2000) (Turkdogan, et.al.,2003) (Carrizales, et.al., 2006) (Khan, et.al., 2008) (Hu, et.al., 2013) (Gress, et.al., 2015) (Dickin, et.al., 2016) (El-Kady, et.al., 2018). The commonly found heavy metals in wastewater include arsenic, cadmium, chromium, copper, lead, nickel, and zinc (Lambert, et.al., 2000). Heavy metals affect the vital organs of the body and may even damage the DNA and alter biological macromolecules deteriorating cellular mechanism (Flora, et.al., 2008). Economically weaker communities 
consume such toxic vegetables and get effected with health problems.

The presence of heavy metal can be detected using different laboratory tests. However, heavy metals can be tested in a laboratory only when their concentration is high enough (minimum concentration required- $\left.0.1 \mathrm{mgml}^{-1}\right)$. When the concentration is very low which is in the case of sewage water, ICP-AES or ICP- MS are the two new-age techniques used. ICP- AES is a leading technology for routine analysis of liquid samples for many elements. Like many other spectrometers, ICP- AES has a source to irradiate or excite the sample i.e. plasma. Plasma, obtained by ionizing a gas through either heating at high temperature or by exposing it to a high voltage, is a mixture of positively charged particles and free electrons. In ICP- AES the liquid sample is turned into an aerosol and then injected into the plasma. The aerosol is formed by a sample induction system consisting of two components: the nebulizer and the spray chamber. The aerosol is sprayed in the plasma chamber. The light emitted from the sample, after excitation from plasma is dispersed into a spectrum. The spectrum is then measured by the CCD (charged coupled device) detector (ICP- OES, 2020). The spectrum detected is evaluated by computer systems and software (Shimadzu, n.d.) (Todolí, et al., 2006) (Atanassova, et.al., 1998).

Several measures are taken to avoid bioaccumulation of heavy metals through filtration of commercial effluents. Many water purification techniques (SODIS, SOLAIR, and UV radiation), reverse osmosis, ceramic filtration, biosand filtration, and clay pot water filtration are available to disinfect the water (Varkey, et.al., 2012). Flotation has been a recent trend employed to separate heavy metal from a liquid phase using bubble attachment, which originated in mineral extraction. Dissolved air flotation (DAF), ion flotation, and precipitation flotation are the most flotation processes for the removal of metal ions from solution (Fu, et.al.,2011). Natural process through synthetic organic naturally processed resins is another method used successfully within the industry for the removal of heavy metals from effluents, advantages pertain to its low sludge generation and fewer timeconsuming. The disadvantage of this method is that it cannot handle the concentrated metal solution because the matrix gets easily fouled by organics and other solids within the wastewater. Moreover, natural process is an art depending on the dimensions of the particle which will be retained, various sorts of membrane filtration like ultrafiltration, nano-filtration, and reverse osmosis are often employed. However, they're costly and susceptible to membrane fouling (Qdais, et.al., 2004) (Barakat, et.al., 2011). Activated charcoal has been widely used as an adsorbent in water treatment applications throughout the planet. However, it remains an upscale material since the upper the standard of activated charcoal, the greater its cost; moreover, it often requires complexing agents to enhance its removal performance for inorganic matters (Babel, et.al., 2003). Recently, numerous approaches are studied for the event of cheaper and simpler technologies like adsorbent/ reactive media of mineral, organic or biological origin represent the new trends within the physicochemical 
water treatment field for the removal of inorganic contaminated water (Barakat, 2011). Low cost and native availability adsorbents include natural materials, modified agricultural and biological waste, or industrial by-products. A number of these materials are often used as adsorbents with little processing; however, the conversion of those materials into activated charcoal, which may be used as an adsorbent for water purification, would improve value, helping industries reduce the value of waste disposal and providing a possible alternative to activated charcoal (Kurniawam et.al., 2006a, b).

Wastewater irrigation is a common reality and benefits the marginal farmers with income generation. The reuse may address the water scarcity, climate change, provide lnutrient rich waters, reduction in usage of manures and also is of economic value. Though the wastewater provides a reliable water supply, despite concerns of water quality; it is important to assess and identify the issues related to its safe and efficient reuse as well as impact on the human communities. Keeping this in view, an attempt has been made to create a prototype of a filter with a combination of adsorbent, reactive media of mineral, organic or biological origin techniques during this study. The effectiveness of the filter with reference to heavy metal filtering and economic viability has been assessed which can be used by a smallscale agriculturist.

\section{Materials and Methods:}

Sample collection and analysis.

The spinach sample was collected from an agricultural field along the railway tracks in Goregaon, Mumbai once a month for 6 months. The spinach leaves were air-dried in dark, crushed using mortar and pestle and filtered using a muslin cloth. The filtrate was centrifuged, and the supernatant was considered for a qualitative test. The presence of heavy metals like lead, arsenic, cadmium, mercury, iron, cyanide, nickel, cobalt, silver, molybdenum was assessed by basic qualitative tests using laboratory grade chemicals (Svehla, 2006) (Table-1) Material selection for filter prototype Many fabrics were used for the filters such as plastic net, polyester satin, polyester spun, polypropylene spun, polypropylene filament, nylon, and cotton cloth. The three fabrics of different texture and composition such as Polyester, polypropylene and Cotton cloth were considered for construction of prototype (Fig-1). The Cotton cloth showed better filtering efficacy among the three and was considered for further study. Cotton cloth was then combined with charcoal and alum for their properties of adsorption and chelating respectively. Various other materials like sand and cotton were used for their porous nature. Efficiency checks were done using the lead water (1 $\left.\mathrm{mgml}^{-1}\right)$ as standard. The laboratory prepared lead water was filtered through the filter fabrics, combinations and prototype filter. The filtrate obtained was treated with dil. $\mathrm{HCL}$ and $\mathrm{KI}$ (Svehla, 2006). This gave a yellow colorization to the filtrate whose intensity is directly proportional to the amount of lead present. The colorimetric estimation at wavelength $470 \mathrm{~nm}$ was done and values were extrapolated from standard graph.

Assembling the water filter.

Layers of cotton, sand, charcoal granules, cotton and cotton cloth laid in respective order from bottom to top 
(figure 2). Lead water $\left(1 \mathrm{mgml}^{-1}\right)$ was filtered through this filter set up in a plastic container to check its efficacy. Qualitatively the presence of Lead was detected by treating the filtrate with dil. $\mathrm{HCl}$ and $\mathrm{Kl}$ and the presence of $\mathrm{Pb}$ confirmed with yellow colour development. The yellow colour thus obtained was quantitatively assessed at wavelength 470nm colorimetrically. To check the durability and reusability of filter and statistically assess the filtration efficacy minimum of 10 readings were considered.

Collection of water sample and its analysis for heavy metal concentration.

Sewage water was collected from several drainage lines 1) near a metal plating factory in Malad (IM), Mumbai. 2)Drainage line near Mithibai College, Vile Parle, Mumbai (NVP). 3) Drainage line in the slum of Ram Mandir, Mumbai (NRM). The water sample was collected in a sterile plastic bottle without any sludge. The heavy metals in water before and after treatment was analyzed qualitatively and quantitatively for the presence of heavy metals by Inductively Coupled Plasma Atomic Emission Spectroscopy (ICP-AES). The ICP-AES at the IIT- Bombay, Powai was used.

\section{Results and Discussion:}

Results

Laboratory tests on Spinach aqueous extracts indicated the presence of heavy metals like lead, arsenic, cadmium, cyanide, cobalt, molybdenum and mercury; moderate presence of nickel and weak presence of Iron. Presence of silver was not found (Table-2).

Known concentration of lead water sock solution (1 $\mathrm{mgml}^{-1}$ ) was used. It was filtered through the filter fabrics such as plastic net, polyester satin, polyester spun, polypropylene spun, polypropylene filament, nylon, and cotton cloth. The presence of lead in the filtrate detected by a chemical test wherein dil. $\mathrm{HCl}$ and $\mathrm{KI}$ are added to the water. Comparing the colour intensity with a stock test tube, polyester satin, polypropylene filament, and cotton cloth can be concluded as the best materials for filtration since the yellow coloration was least in their filterates tubes indicating low $\mathrm{Pb}$ concentration. Hence these three fabrics were combined with different chelating agents and adsorbents to check the best combination. The fabrics were combined with alum and charcoal granules in different combinations and efficacy check was done. The filtrate was tested for the presence of lead and the optical density of filtrate was checked at 470nm. Their concentrations were extrapolated based on the standard graph of lead and found to be Polyester Satin \& charcoal- $0.035 \mathrm{mgml}^{-1}$, Polyester Satin \& Alum- $0.069 \mathrm{mgml}^{-1}$, Polypropylene filament \& Alum - $0.115 \mathrm{mgml}^{-1}$, Cotton cloth \& alum - $0.028 \mathrm{mgml}^{-1}$ and Cotton cloth \& charcoal $-0.0115 \mathrm{mgml}^{-1}$. (Graph 1) .Cotton cloth and alum combination was eliminated from filter design due to alum's high solubility in water causing it to seep into the filtrate. Since the lowest concentration was noticed with cotton cloth and charcoal, the combination was considered for further development of prototype.

The filter prototype prepared was used to filter the lead water, consecutively ten times to check the efficacy of the filter. The concentration of lead was $0.04 \mathrm{mgml}$ 1 initially during the first filter and by the time we used the filter for the tenth time, 
the concentration of lead in the filtrate was reduced to almost zero. This indicated the increasing efficacy of filters with the use.

Sewage water collected from different locations; NRM- Drainage in Ram Mandir, NVP- Drainage beside Mithibai College, Vile Parle and IM- Drainage in Industrial District of Malad; showed presence of heavy metals on performing ICP- AES. Elements namely- Aluminum (Al), Boron (B), Barium (Ba), Calcium (Ca), Chromium $(\mathrm{Cr})$, Copper (Cu), Iron (Fe), Potassium $(\mathrm{K})$, Magnesium (Mg), Manganese (Mn), Sodium (Na), Phosphorous (P), Sulphur (S), Silicon (Si), Strontium (Sr), Titanium (Ti) and Zinc (Zn) - were found in all the three water samples. NRM and IM water samples also showed presence of Cadmium (Cd), Molybdenum (Mo), Nickel (Ni) and Lead (Pb). IM samples showed unique presence of Cobalt (Co), Selenium (Se), Tin (Sn) and Vanadium (V). From these samples, the one collected from industrial district of Malad (IM) was qualitatively and quantitatively analyzed before and after treatment. The reason being it represented overall 25 metal and heavy metal components as compared to NRM (21) and NVP (17) stations. The metals which the vegetables bioaccumulate and cause maximum damage to humans were selected for this analysis. These metals were Cadmium (Cd), Cobalt (Co), Chromium (Cr), Nickel $(\mathrm{Ni})$, Lead $(\mathrm{Pb})$, Zinc (Zn) and Vanadium (V). Their concentration (in ppm) before filtration were $0.221,0.023,0.783,8.269$, $0.331,1.371$ and 0.032 respectively. The concentration values (in ppm) for $\mathrm{Cd}, \mathrm{Co}$, $\mathrm{Ni}, \mathrm{Pb}$ and $\mathrm{V}$ were reduced to less than 0.01 after one use of the filter. The concentrations of $\mathrm{Zn}$ and $\mathrm{Cr}$ were less than 0.01 ppm after second and third use of filter respectively. The results indicated that very good response was noticed from second use of the filter and remained stable after. Chart 2 shows the log values of concentration of metal before and after filtration. 
Table 1. Qualitative tests to detect the presence of Heavy metals

\begin{tabular}{|c|c|c|c|}
\hline Heavy metals & Reactions & Observation & Inference \\
\hline Lead & $\begin{array}{l}\text { Sample+ } \\
\mathrm{HCl}+\mathrm{KI}\end{array}$ & $\begin{array}{l}\text { Yellow } \\
\text { precipitate }\end{array}$ & Lead present \\
\hline Arsenic & $\begin{array}{l}\text { Sample }+\mathrm{NH}_{4} \mathrm{OH} \\
\text { (till alkaline) }\end{array}$ & $\begin{array}{l}\text { White } \\
\text { precipitate }\end{array}$ & $\begin{array}{l}\text { Arsenic } \\
\text { present }\end{array}$ \\
\hline Cadmium & Sample+ $\mathrm{NH}_{3}$ & $\begin{array}{l}\text { White } \\
\text { precipitate }\end{array}$ & $\begin{array}{l}\text { Cadmium } \\
\text { confirmed }\end{array}$ \\
\hline Mercury & Sample+ $\mathrm{NaOH}$ & $\begin{array}{l}\text { Black } \\
\text { precipitate }\end{array}$ & $\begin{array}{l}\text { Mercury } \\
\text { confirmed }\end{array}$ \\
\hline Iron & $\begin{array}{l}\text { Sample+ } \\
\mathrm{K}_{4} \mathrm{Fe}(\mathrm{CN})_{6}\end{array}$ & $\begin{array}{l}\text { Persian blue } \\
\text { color }\end{array}$ & $\begin{array}{l}\text { Iron } \\
\text { confirmed }\end{array}$ \\
\hline Cyanide & Sample $+\mathrm{HgCl}_{2}$ & $\begin{array}{l}\text { Grey } \\
\text { precipitate }\end{array}$ & $\begin{array}{l}\text { Cyanide } \\
\text { confirmed }\end{array}$ \\
\hline Nickel & $\begin{array}{l}\mathrm{Sample}+\mathrm{NaOH}+ \\
\mathrm{Br}_{2} \text { water }\end{array}$ & $\begin{array}{l}\text { Black } \\
\text { precipitate }\end{array}$ & Nickel present \\
\hline Cobalt & $\begin{array}{l}\text { Sample }+\mathrm{NH}_{4} \mathrm{OH} \\
+\quad \mathrm{CH}_{3} \mathrm{COOH}+ \\
\mathrm{KNO}_{2} \text { crystals }\end{array}$ & $\begin{array}{l}\text { Yellow } \\
\text { precipitate }\end{array}$ & $\begin{array}{l}\text { Cobalt } \\
\text { confirmed }\end{array}$ \\
\hline Silver & Sample $+\mathrm{NaOH}$ & $\begin{array}{l}\text { Brown } \\
\text { precipitate }\end{array}$ & $\begin{array}{l}\text { Silver } \\
\text { confirmed }\end{array}$ \\
\hline Molybdenum & Sample+ dil. $\mathrm{HCl}$ & $\begin{array}{l}\text { White } \\
\text { precipitate }\end{array}$ & $\begin{array}{l}\text { Molybdenum } \\
\text { confirmed }\end{array}$ \\
\hline
\end{tabular}


Table 2. Qualitative analysis of spinach sample.

\begin{tabular}{|l|l|}
\hline Heavy metals & Presence \\
\hline Lead & +++ \\
\hline Arsenic & +++ \\
\hline Cadmium & +++ \\
\hline Mercury & +++ \\
\hline Iron & + \\
\hline Cyanide & +++ \\
\hline Nickel & ++ \\
\hline Cobalt & +++ \\
\hline Silver & - \\
\hline Molybdenum & +++ \\
\hline \begin{tabular}{l} 
(key - +++: strongly present; ++: moderately present; \\
$+:$ weakly present; - : absent.) \\
\hline
\end{tabular} \\
\hline
\end{tabular}

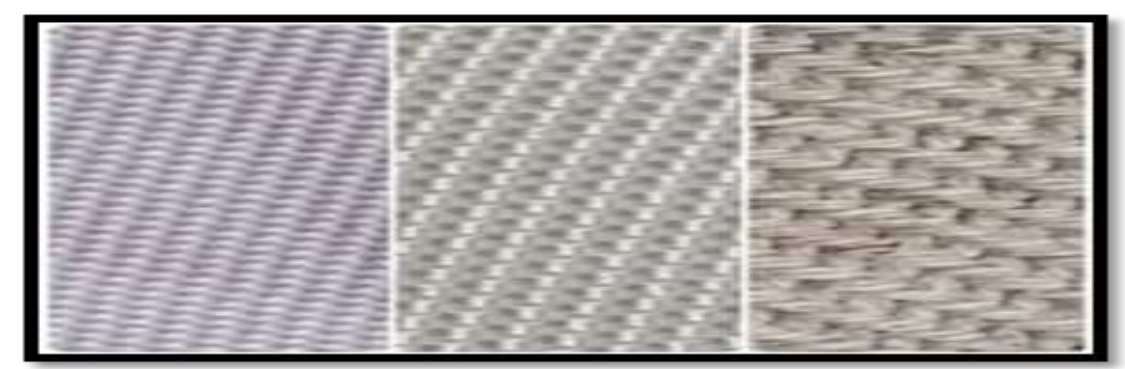

Figure 1. Cloth material considered for prototype (a: polyester satin. b: polypropylene filament. c: cotton cloth.) 


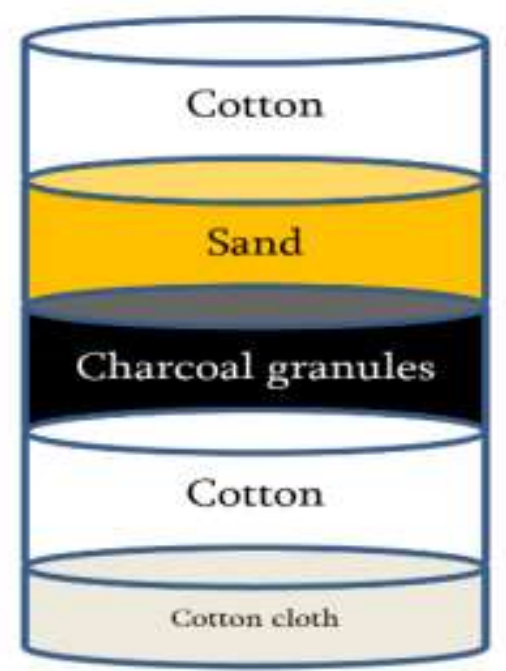

Figure 2. Model of water filter.

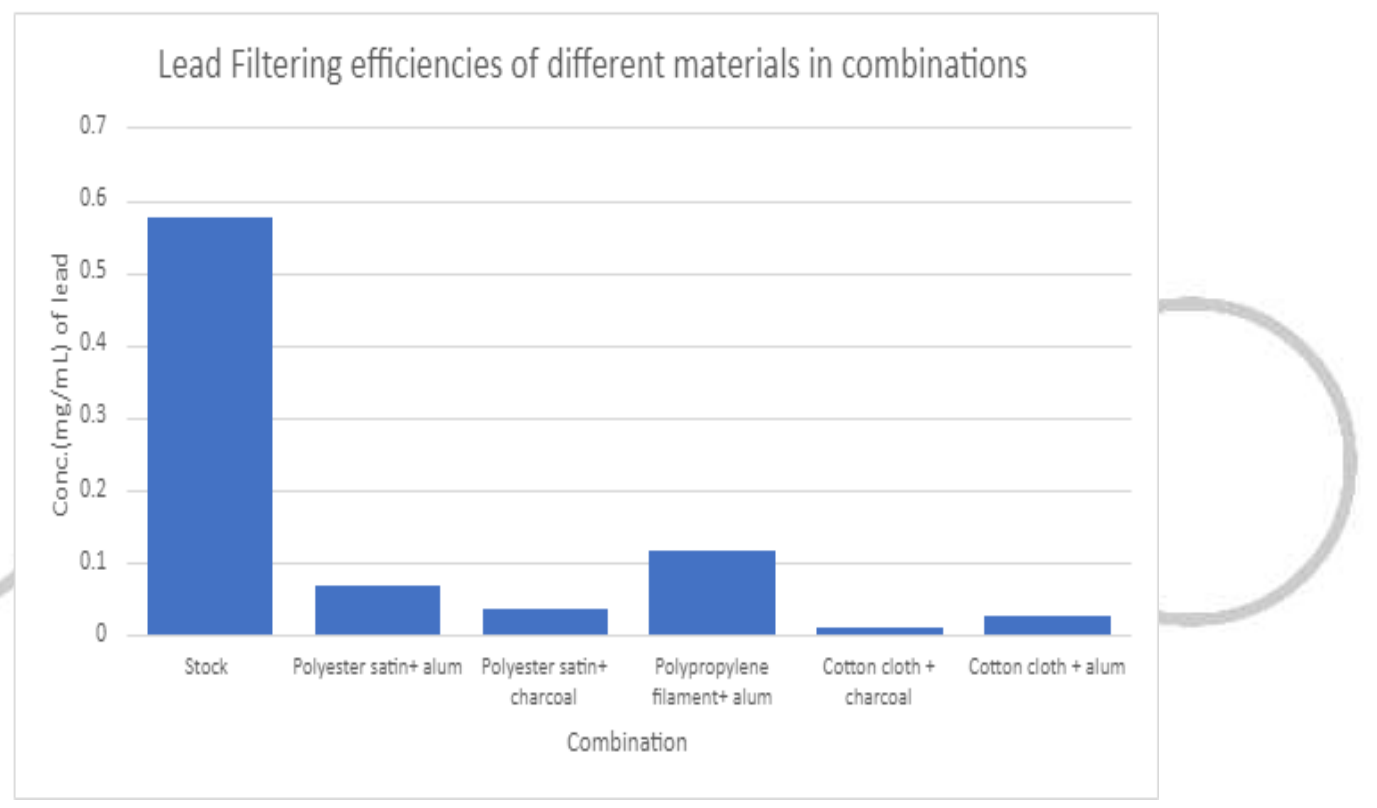

Chart 1. Lead filtering efficacy analysis of filtering materials and cloth combinations 


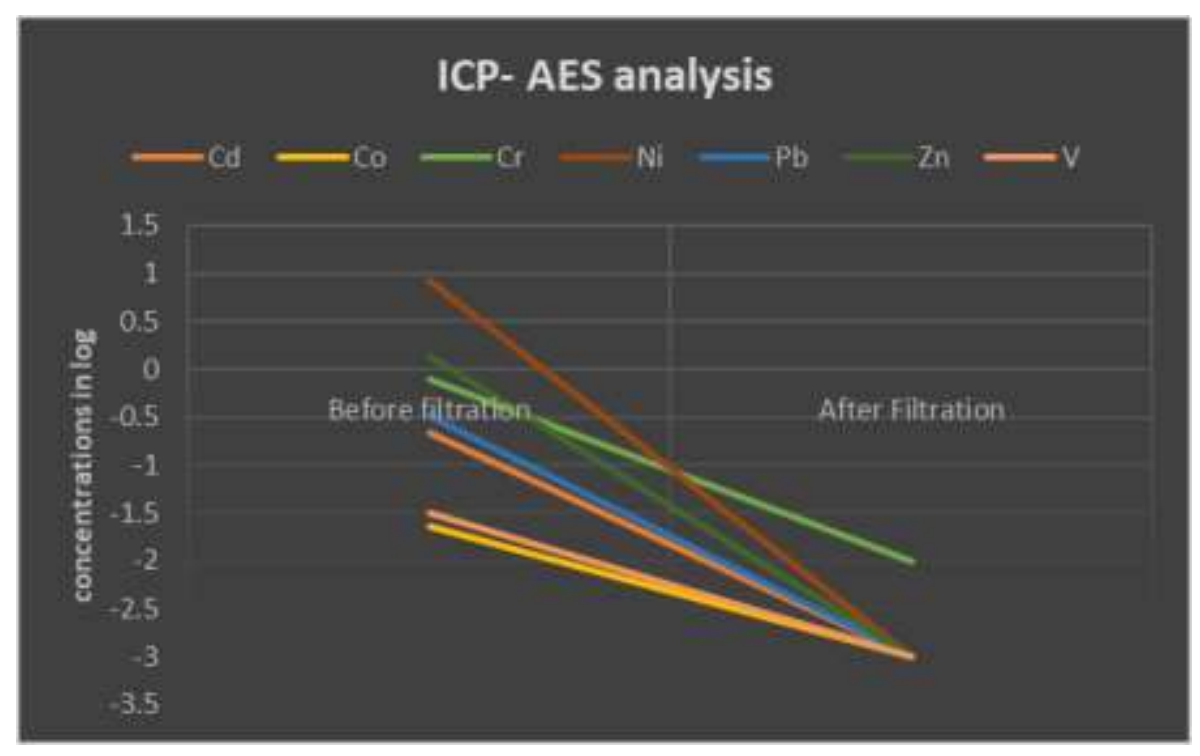

Chart 2.

\section{Discussions}

Modern agricultural practices have caused agricultural pollution resulting in degradation of the ecosystem and therefore increased application of agrochemicals and inorganic fertilizers (Malik, et.al., 2017). Additionally, land application of sewage sludge, organic waste manure, industrial byproducts and irrigation with wastewater are major sources of heavy metals into agricultural systems (Khan, et.al., 2013) (Srivastava, et.al., 2015) (Tóth, et.al., 2016) (Sharma, et.al., 2007) (Woldetsadik, et.al., 2017). Soils contaminated by heavy metals from agricultural activities have raised serious concern in recent decades regarding a possible risk to human health through the direct intake, bioaccumulation through the food chain, and their impacts on the ecological system (Wong, et.al., 2002) (Cheng, 2003). Essential heavy metals [copper (Cu), zinc (Zn), and manganese $(\mathrm{Mn})]$, as well as nonessential heavy metals [cadmium (Cd), chromium (Cr), manganese $(\mathrm{Mn})$ and lead $(\mathrm{Pb})]$, are considered highly toxic for human and aquatic life (Ouyang, et.al., 2002). Recent data revealed that adverse health effects of cadmium and lead exposure may occur even at lower exposure levels leading to kidney damage, bone defects and fractures, and neurotoxic effects in children (Järup, 2003). A specific amount of $\mathrm{Cr}$ (III) is needed for normal body functions, while its high concentrations along with $\mathrm{Cr}(\mathrm{IV})$ may cause toxicity, including liver and kidney problems and genotoxic carcinogens (Knight, et.al., 1997). Irrespective of the origin of the metals within the soil, excessive levels of the many metals may result in soil quality degradation, crop yield reduction, and poor quality of agricultural products, posing significant hazards to human, animal, and ecosystem health (Long, et.al., 2002). The government of India has taken several measures for the reduction/ eradication of heavy metal pollution in soil and water. However, the increasing practice by farmers in agriculture due to the low economic background has made us find a solution for it. Phytoremediation and bioremediation are the most effective method of removal of heavy metal contamination from the soil. Several industries have effluent treatment plants for the 
treatment of the waste which reduces $70 \%$ of soil and water pollution. However, the increasing population and demand resulted to grow crops and vegetables in large quantity leading to increasing agricultural fields along the railway tracks which is irrigated using sewage water. Water filtering device based on Carbon nanotubes (CNTs) have attracted great interest due to their unique morphologies leading to enhanced surface sorption properties and multi-component sorption of metal ions (Zhao, et.al., 2011). The sorption mechanism was governed by the surface features, ion exchange process, and electrochemical potential (Gao, et.al., 2003). However, all these techniques are time-consuming and costly. Also, these techniques require absolute expertise in its usage. The current water filter model designed is time-saving and cost-effective. It is the combination of a chelating agent, adsorbents, and large particulate retentive. However, commercial usage and field trials of the same would give a better idea of the efficacy of the model. In laboratory conditions, subsequent use of the filter is found to reduce the heavy metal load in sewage to almost zero.

Concluding indigenous, effective, cost effective filters with an ability to reduce the heavy metal contamination in nutrient enriched sewage waters will be the futuristic approach for efficient use of waste waters in the process of irrigation. These methods are progressive and encourage the crops with zero heavy metal accumulation that could be hazardous for human population.

\section{Acknowledgement:}

We would like to thank Late Dr. Rajpal Shripat Hande, Principal, SVKM's Mithibai College for allowing us to use the infrastructure. A heartfelt gratitude to SAIF IIT Bombay for processing our samples in ICP-AES instrument. We thank Mr. Piyush Jesrani founder of Filter Service, Mumbai, Maharashtra, India for providing us with filter fabrics. We thank Mr. Nilesh Nirmal and Mrs. Heena Nirmal for helping us collect sewage water samples. We thank Ms. Pari Nirmal for helping us with the digital pictures used in this paper.

\section{References:}

1. Anand SS, Hawkes C, de Souza RJ, Mente A, Dehghan M, Nugent R, Zulyniak MA, Weis T, Bernstein AM, Krauss RM, Kromhout D, Jenkins DJA, Malik V, MartinezGonzalez MA, Mozaffarian D, Yusuf S, Willett WC, Popkin BM, Food Consumption and its Impact on Cardiovascular Disease: Importance of Solutions Forced on the Globalized Food System: A Report from the Workshop Convened by the World Heart Federation. J Am Coll Cardiol. 2015 Oct 6; 66(14):1590-1614.

2. Atanassova D, Stefanova V, Russeva E. Co-precipitative pre-concentration with sodium diethyldithiocarbamate and ICPAES determination of Se, Cu, Pb, Zn, Fe, $\mathrm{Co}, \mathrm{Ni}, \mathrm{Mn}, \mathrm{Cr}$ and $\mathrm{Cd}$ in water. Talanta. 1998;47(5);1237-1243

3. Artinian NT, Fletcher GF, Mozaffarian D, Kris- Etherton P, Van Horn L, Lichtenstein $A H$, Kumanyika S, Kraus WE, Fleg JL, Redeker NS, Meininger JC, Banks J, StuartShor EM, Fletcher BJ, Millere TD, Hughes S, Braun LT, Kopin LA, Berra K, Hayman LL, Ewing LJ, Ades PA, Durstine JL, HoustonMiller $\mathrm{N}$, Burke LE, Interventions to promote physical activity and dietary lifestyle changes for cardiovascular risk factor reduction in adults: a scientific 
statement from the American Heart Association. American Heart Association Prevention Committee of the Council on Cardiovascular Nursing. Circulation. 2010 Jul 27; 122(4):406-41.

4. Babel S. and T.A. Kurniawan. Low-cost adsorbents for heavy metals uptake from contaminated water: A review. Journal of Hazardous Materials, 2003, B97, 219-243.

5. Barakat M.A. New trends in removing heavy metals from industrial wastewater. Arabian Journal of Chemistry. 2011, 4, 361-377.

6. Carrizales L., I. Razo, J.I. Tellez- Hernandez, R. Torres Nerio, A.C. Cubillas, F. DiazBarriga. Exposure to arsenic and lead of children living near a CU-smelter in San Luis Potosi, Mexico: importance of soil contamination for exposure of children Environ. Res. 101, 2006, pp. 1-10.

7. Cheng S., "Heavy metal pollution in China: origin, pattern and control," Environmental Science and Pollution Research, vol. 10, no. 3, pp. 192-198, 2003.

8. CPCB. Status of water supply, wastewater generation and treatment in class -1 cities and class-ll towns of India. Control of Urban Pollution series: CUPS/70/2009-10. New Delhi: Central Pollution Control Board, Ministry of Environment and Forests. 2009.

9. Danjuma M.S. and Abdulkadir B. Bioaccumulation of heavy metals by leafy vegetables grown with industrial effluents: A review. Bayero Journal of Pure and applied Sciences. 2018, $11(2): 180-$ 185.

10. Dickin S.K., C.J. Schuster-Wallace, $M$. Qadir, K. Pizzacalla. A review of health risk and pathways for exposure to wastewater use in agriculture Environ. Health Perspect. 124(7), 2016, pp. 900909.
11.Doshi, P.P., \& Zele, R.A. Monitoring The Status of Agricultural Activities Carried Along the Railway Tracks in Mumbai Region. Int. J. Environmental Sciences, 3(3), 131-138. 2014.

12. El- Kady A.A., M.A. Abdel-Wahhab. Occurrence of trace metals in foodstuffs and their health impact Trends Food Sci. Technol. 75, 2018, pp. 36-45.

13. Flora SJS, Mittal M, Mehta A. Heavy Metal induced oxidative stress \& its possible reversal by chelation therapy. Indian J Med Res. 2008; 128:501-523

14. Fu F., Q. Wang. Removal of heavy metal ions from wastewater: A review. Journal of Environmental Management. 201 1, 92, 407-418.

15. Gao Z., T.J. Bandosz, Z. Zhao, M. Han, J. Qiu. Investigation of Factors Affecting adsorption of transition metals on oxidized carbon nanotubes. Journal of Hazardous Materials. 2003, 167, 357-365.

16. Gold RJ, Scriver CG, The amino acid composition of hair from different racial origins. Clin Chim Acta. 1971 Jul; 33(2):465-6.

17. Gress J., L.M. de Oliveira, E.B. da Silva, J.M. Lessl, P.C. Wilson, T. Townsend, L.Q. Ma. Cleaning-induced arsenic mobilization and chromium oxidation from CCA-wood deck: potential risk to children Environ. Int. 82, 2015, pp.35-40.

18. Hu J., F. Wu, S. Wu, Z. Cao, X. Lin, M.H. Wong. Bioaccessibility, dietary exposure and human risk assessment of heavy metals from market vegetables in Hong Kong revealed with an in vitro gastrointestinal model. Chemosphere. 91, 2013, pp. 455-461.

19. ICP- OES Spectrometers, O2020 SPECTRO Instruments $\mathrm{GmbH}$. All rights reserved. URL:

https://www.spectro.com/products/icpoes-aes-spectrometers

2021 March Edition | www.jbino.com | Innovative Association 
20.lyengar V., P. Nair. Global outlook on nutrition and the environment: meeting the challenges of the next millennium Sci. Total Environ. 249, 2000, pp. 331-346.

21. Järup L., "Hazards of heavy metal contamination," The British Medical Bulletin, vol. 68, pp. 167-182, 2003.

22. Khan M.U., Malik R.N., and Muhammad S. Human health risk from Heavy metal via food crops consumption with wastewater irrigation practices in Pakistan. Chemosphere. 2013, 93,2230-2238.

23. Khan S., L. Aijun, S. Zhang, Q. Hu, Y. Zhu. Accumulation of polycyclic aromatic hydrocarbons and heavy metals in lettuce grown in soils contaminated with long term wastewater irrigation. J. Hazard. Mater. 152, 2008, pp. 506-515.

24. Knight C., J. Kaiser, G.C. Lalor, H. Robotham, and J.V. Witter, "Heavy metals in surface water and stream sediments in Jamaica," Environmental Geochemistry and Health, vol. 19, no. 2, pp.63-66, 1997.

25. Kurniawan T.A., G.Y.S. Chan, W. LO, S. Babel. Comparisons of low-cost adsorbents for treating wastewaters laden with heavy metals. Science of the Total Environment. 2006a, 366, 409-426.

26. Kurniawan T.A., G.Y.S. Chan, W.H. LO, S. Babel. Physicochemical treatment techniques for wastewater laden with heavy metals. Chemical Engineering Journal. 2006b, 118, 83-98.

27. Lambert $M$, Leven BA, Green RM. New methods of cleaning up heavy metal in soils and water; Environmental science and technology briefs for citizens; Manhattan, KS: Kansas State University; 2000

28. Lancet. Global, regional, and national age- sex specific all- cause and causespecific mortality for 240 causes of death, 1990-2013: a systematic analysis for the
Global Burden of Disease Study 2013, GBD 2013 Mortality and Cause of Death Collaborators. 2015 Jan 10; 385(9963):11771.

29. Long XX, Yang XE, Ni WZ. Current status and prospective on phytoremediation of heavy metal polluted soils. J Appl. Ecol. 2002; 13:757-62.

30. Malik Z., Ahmad M., Abassi G.H., Dawood M., Hussain A., and Jamil $M$. "Agrochemicals and soil microbes: interaction for soil health", in Xenobiotics in the Soil Environment: Monitoring, Toxicity and Management, ed M.Z. Hashmi (Cham: Springer International Publishing). 2017, 139-152.

31. Ouyang Y., J. Higmam, J. Thompson, T. O'Toole, and D. Campbell, "Characterization and spatial distribution of heavy metals in sediment from Cedar and Ortega rivers subbasin," Journal of Contaminant Hydroligy, vol. 54, no. 1-2, pp. 19-35, 2002.

32. Qdais H.A., H. Moussa. Removal of heavy metals from wastewater by membrane processes: a comparative study. Desalination. 2004, 164(2), 105-110.

33. Rawat, M.; Ramanathan, A.; Subramanian, V. Quantification and distribution of heavy metals from smallscale industrial areas of Kanpur city, India. Journal of Hazardous Materials 172(23):1145-1149. 2009

34. Sharma R.K., Agrawal M., and Marshall F. Heavy metal contamination of soil and vegetables in suburban areas of Varanasi, India. Ecotoxicol. Environ. Saf. 2007, 66, 258-266

35. Shimadzu, Inductively Coupled Plasma Atomic Emission Spectroscopy (ICP AES). URL:

https://www.ssi.shimadzu.com/industry/e nvironmental/icp-aes.html 
36. Srivastava V., Ismail S.A., Singh P., and Singh R.P. Urban solid waste management in the developing world with emphasis on India: challenges and opportunities. Rev. Environ. Sci. Biol. 2015, 14, 317-337.

37. Svehla G. Vogel's qualitative analysis. Chapter 3- reactions of cation, Chapter 4- reactions of anions, chapter 6reactions of some less common ions. Pearson Publication, 2006, 7th edition.

38. Tea I, Le Guennec A, Frasquet- Darrieux $M$, Julien $M$, Romel K, Antheaume I, Hankard R, Robins RJ, Simultaneous determination of natural- abundance delta15N values and quantities of individual amino acid in proteins from milk of lactating women and from infant hair using gas chromatography/isotope ratio mass spectrometry. Rapid Common Mass Spectrom. 2013 Jun 30; 27(12):1345-53.

39. Todolí, José \& Mermet, Jean. Sample introduction systems for the analysis of liquid microsamples by ICP-AES and ICPMS. Spectroscopy. 2006, 61.239-283.

40. Tóth G., Hermann T., Da Silva M.R., and Montanarella L. Heavy metals in agricultural solids of the European Union with implications for food safety. Environ. Pollut. 2016, 88, 299-309.
41.Turkdogan M.K., K. Fevzi, K. Kazim, T. llyas, U. Ismail. Heavy Metals in soil, vegetables and fruits in the endemic upper gastrointestinal cancer region of Turkey Environ. Toxicol. Pharmacol. 13, 2003, pp. 175-179.

42. Varkey A.J. and M.D. Dlamini. Point-of-use water purification using clay pot water filters and copper mesh. Archives. 2012, Vol 38 No. 5.

43. Woldetsadik D., Drechsel P., Keraita B., Itanna F., and Gebrekidan H. Heavy metal accumulation and health risk assessment in wastewater-irrigated urban vegetable farming sites of Addis Ababa, Ethiopia. Int. J. Food Contam. 2017, 4:9.

44.Wong S.C., X.D. Li, G. Zhang, S.H.G. Qi, and Y.S. Min, "Heavy metals in agricultural soils of Pearl River Delta, South China," Environmental Pollution, vol.199, no. 1, pp. 33-44, 2002.

45. Zhao G., X. WU, X. Tan, X. Wang. Sorption of Heavy Metal lons from Aqueous Solutions: A Review. The Open Colloid Science Journal (4), 2011, 19-31. 